\title{
A Confounding Case of Inherited Factor V Deficiency Complicated by Inhibitors at First Presentation
}

\author{
Hema Subramanian ${ }^{a}$ Rakhee Kar $^{\mathrm{a}}$ Deepak Charles $^{\mathrm{b}}$ Hitha Babu $^{\mathrm{b}}$ Pagadalu Ambika $^{\mathrm{a}}$ \\ Tarun Kumar Dutta ${ }^{\mathrm{b}}$
}

a Department of Pathology (Hematology Section), Jawaharlal Institute of Postgraduate Medical Education and Research, Puducherry, India;

${ }^{b}$ Department of Internal Medicine (Clinical Hematology Unit), Jawaharlal Institute of Postgraduate Medical Education and Research,

Puducherry, India

\section{Keywords}

Factor $\mathrm{V}$ deficiency · Coagulation factor inhibitors .

Correction studies $\cdot$ Inhibitor screen

\section{Summary}

Introduction: Inherited factor V deficiency / Owren's disease has varied clinical manifestations ranging from asymptomatic laboratory abnormalities to massive hemorrhage. The acquired form due to inhibitors following antibiotic therapy, infection, or surgery is less common, and spontaneous development of inhibitors is not known. Case Report: An 18-year-old boy presented with bleeding axillary and groin ulcers. At the age of 15, due to recurrent epistaxis and gum bleed, he was diagnosed with acquired factor $V$ deficiency with positive inhibitor screen and treated with fresh frozen plasma (FFP) transfusion and temporary azathioprine. Coagulation workup at his current presentation also revealed acquired factor $\checkmark$ deficiency with presence of inhibitors. The tests were repeated after 6 weeks of intermittent FFP transfusion, and the differences observed included negative inhibitor screen and complete correction on mixing studies, but factor $V$ level was $2 \%$. Discussion: Evidence of inhibitors at presentation favored acquired disease. However, younger age of onset, detection of inhibitors 1 year after first episode of self-regressing bleed, lack of identifiable triggers, and persistent bleeding with reduced factor levels after disappearance of inhibitors favored inherited factor V deficiency. Conclusion: In this case report, we have described an interesting case of severe inherited factor $V$ deficiency with spontaneous appearance and disappearance of inhibitors exhibiting nonspecific factor inhibitory activity.

(C) 2016 S. Karger GmbH, Freiburg

\section{Introduction}

Inherited factor V deficiency / parahemophilia / Owren's disease (incidence $1: 1$ million) is a diagnostic challenge due to its dramatic diversity in clinical manifestations, ranging from asymptomatic laboratory abnormalities to massive life-threatening hemorrhagic episodes. Thus there is a compelling need to identify and diagnose the condition before bleeds occur at critical sites. Acquired factor $\mathrm{V}$ deficiency is even more rare due to development of inhibitors against factor $\mathrm{V}$ following antibiotic therapy, infection, malignancy, or surgery, although idiopathic occurrence in elderly patients has also been described in $39 \%$ of cases [1]. The data on spontaneous disappearance of these inhibitors is lacking although one case report quoted that factor $\mathrm{V}$ inhibitors disappeared within 10 weeks of initial detection [2]. Evidence for factor V deficiency in initial laboratory screening is given by prolongation of both prothrombin time (PT) and activated partial thromboplastin time (aPTT) with normal thrombin time (TT). In the inherited form, both abnormalities are corrected by mixing the patient plasma with a normal plasma pool, whereas in the acquired form the correction is partial. The final diagnosis is made by demonstration of an isolated reduction of factor $\mathrm{V}$ levels and in the latter by exclusion of presence of nonspecific inhibitors such as lupus anticoagulant, a positive inhibitor screen and quantitation of inhibitors by Bethesda assay. We here report a case of a young patient with no history of triggering factors for inhibitor development who presented with low factor V level as well as a positive inhibitor screen.

\section{Case Report}

An 18-year-old boy, born out of a non-consanguineous marriage with no family history of bleeding diathesis, presented with bleeding axillary and groin ulcers. His first episode was a spontaneously subsiding mucocutaneous bleed-

\section{KARGER}

() 2017 S. Karger GmbH, Freiburg 
Table 1. Consolidated findings of coagulation workup on five occasions

\begin{tabular}{|c|c|c|c|c|c|}
\hline \multirow{2}{*}{$\begin{array}{l}\text { Parameter (normal reference } \\
\text { range with units) }{ }^{\sharp}\end{array}$} & \multicolumn{2}{|c|}{ At first presentation, (age 15 years) } & \multicolumn{3}{|c|}{ At second presentation, (age 18 years) } \\
\hline & $\begin{array}{l}\text { initial workup } \\
\text { (December 2010) }\end{array}$ & $\begin{array}{l}\text { subsequent } \\
\text { workup (outside) } \\
\text { (January 2011) }\end{array}$ & $\begin{array}{l}\text { initial workup } \\
\text { (outside) } \\
\text { (December 2013) }\end{array}$ & $\begin{array}{l}\text { subsequent } \\
\text { workup } \\
\text { (July 2014) }\end{array}$ & $\begin{array}{l}\text { post } 6 \text { weeks of FFP } \\
\text { transfusion } \\
\text { (September 2014) }\end{array}$ \\
\hline Bleeding time (2-7 min) & $3 \mathrm{~min}$ & $4 \mathrm{~min}$ & $5 \mathrm{~min}$ & $3 \mathrm{~min}$ & $3 \mathrm{~min}$ \\
\hline Platelet count $\left(280 \pm 130 \times 10^{9} / \mathrm{l}\right)$ & 400 & 370 & 195 & 395 & 400 \\
\hline \multicolumn{6}{|l|}{ PT (11-16s) } \\
\hline Test & $>70 \mathrm{~s}$ & $120 \mathrm{~s}$ & $111 \mathrm{~s}$ & $51 \mathrm{~s}$ & $47 \mathrm{~s}$ \\
\hline Control & $14 \mathrm{~s}$ & $14 \mathrm{~s}$ & $12 \mathrm{~s}$ & $13 \mathrm{~s}$ & $14 \mathrm{~s}$ \\
\hline $1 / 2 \operatorname{mix}^{*}$ & $53 \mathrm{~s}$ & $81 \mathrm{~s}$ & & $39 \mathrm{~s}$ & $15 \mathrm{~s}$ \\
\hline \multicolumn{6}{|l|}{ aPTT (26-40s) } \\
\hline Test & $>120 \mathrm{~s}$ & $>180 \mathrm{~s}$ & $180 \mathrm{~s}$ & $134 \mathrm{~s}$ & $143 \mathrm{~s}$ \\
\hline Control & $31 \mathrm{~s}$ & $40 \mathrm{~s}$ & $26 \mathrm{~s}$ & $26 \mathrm{~s}$ & $31.6 \mathrm{~s}$ \\
\hline $1 / 2 \operatorname{mix}^{*}$ & CNP: $89 \mathrm{~s}$ & CNP: 89 s & ND & CNP: $89 \mathrm{~s}$ & CNP $33.8 \mathrm{~s}$ \\
\hline \multirow[t]{4}{*}{$1 / 2$ mix with specific FDPs $\Psi$} & \multicolumn{2}{|l|}{ FVDP: $>120 \mathrm{~s}$} & & \multicolumn{2}{|l|}{ FVDP: $>180 \mathrm{~s}$} \\
\hline & \multicolumn{2}{|l|}{ FXDP: $72 \mathrm{~s}$} & & \multirow{2}{*}{\multicolumn{2}{|c|}{ FXDP: $72 \mathrm{~s}$}} \\
\hline & \multirow{2}{*}{\multicolumn{2}{|c|}{$\begin{array}{l}\text { FVIIIDP: } 90 \mathrm{~s} \\
\text { FIXDP: } 97 \mathrm{~s}\end{array}$}} & & & \\
\hline & & & & & \\
\hline \multicolumn{6}{|l|}{ Thrombin time (15-19s) } \\
\hline Test & $14 \mathrm{~s}$ & $13 \mathrm{~s}$ & ND & ND & ND \\
\hline Control & $14 \mathrm{~s}$ & $12-16 \mathrm{~s}$ & ND & ND & ND \\
\hline \multicolumn{6}{|l|}{ Factor assays } \\
\hline FII & ND & 92.4 & ND & ND & - \\
\hline FV & ND & $<1$ & $<1$ & ND & 2 \\
\hline FX & ND & 61.2 & ND & ND & 120 \\
\hline FVII & ND & 58.8 & ND & ND & - \\
\hline FVIII & ND & 303 & ND & ND & 144 \\
\hline FIX & ND & 81 & ND & ND & 170 \\
\hline $\begin{array}{l}\text { Serum antibodies to } \beta 2 \text {-glycoprotein } \\
\text { and cardiolipin }\end{array}$ & $\begin{array}{l}\text { within normal } \\
\text { limits }\end{array}$ & ND & ND & $\begin{array}{l}\text { within normal } \\
\text { limits }\end{array}$ & ND \\
\hline Inhibitor assay (Bethesda units) & ND & 512 & ND & ND & ND \\
\hline $\begin{array}{l}\text { CNP = Control normal plasma; FDP } \\
{ }^{\#} \text { Reference ranges and normal values } \\
*_{1} / 2 \text { mix }=50: 50 \text { mixture, patient }: \text { CN } \\
\psi_{1 / 2} \text { mix }=50: 50 \text { mixture, patient }: \text { spe }\end{array}$ & $\begin{array}{l}\text { or-deficient plasma; } \\
\text { ling to [3]. } \\
\text { DP. }\end{array}$ & $=$ not done. & & & \\
\hline
\end{tabular}

Table 2. Inhibitor screening performed on three occasions

\begin{tabular}{|c|c|c|c|c|c|c|c|c|c|}
\hline & \multicolumn{9}{|c|}{ PT-based inhibitor screen } \\
\hline & \multirow{2}{*}{\multicolumn{3}{|c|}{$\frac{\text { at first presentation }}{\text { December } 2010}$}} & \multicolumn{6}{|c|}{ at second presentation } \\
\hline & & & & \multicolumn{3}{|c|}{ July 2014} & \multicolumn{3}{|c|}{ September 2014 (post FFP) } \\
\hline & $0 \mathrm{~h}$ & $1 \mathrm{~h}$ & $2 \mathrm{~h}$ & $0 \mathrm{~h}$ & $1 \mathrm{~h}$ & $2 \mathrm{~h}$ & $0 \mathrm{~h}$ & $1 \mathrm{~h}$ & $2 \mathrm{~h}$ \\
\hline Fresh mix & $44.7 \mathrm{~s}$ & $58.3 \mathrm{~s}$ & $78.4 \mathrm{~s}$ & $54.3 \mathrm{~s}$ & $93.5 \mathrm{~s}$ & $110.7 \mathrm{~s}$ & $14.9 \mathrm{~s}$ & $16.9 \mathrm{~s}$ & $21.8 \mathrm{~s}$ \\
\hline Incubated $\mathrm{mix}^{\$}$ & $44.7 \mathrm{~s}$ & $103.6 \mathrm{~s}$ & $>120 \mathrm{~s}$ & $54.3 \mathrm{~s}$ & $94.2 \mathrm{~s}$ & $121.4 \mathrm{~s}$ & $14.9 \mathrm{~s}$ & $15.0 \mathrm{~s}$ & $18.4 \mathrm{~s}$ \\
\hline
\end{tabular}

•Fresh mix = incubate patient plasma and control normal plasma separately, mix and test at the indicated time $(0,1,2 \mathrm{~h})$.

${ }^{\$}$ Incubated mix $=$ mix 1:1 of patient plasma + control normal plasma and incubate, test at indicated time $(0,1,2 \mathrm{~h})$. 
ing episode at 14 years of age. There was no history of hospital admission or transfusion of any sort at that point. Moreover, there was no history of any drug intake. The patient is an only child. Baseline PT and aPTT of the parents were normal. At the age of 15, due to recurrent epistaxis and gum bleed, he was diagnosed to suffer from factor $\mathrm{V}$ deficiency with inhibitors but was lost to followup. Detailed coagulation workup done in our hospital and in another hospital (post diagnosis patient had visited another center for treatment) was summarized in tables 1 and 2 . The patient was examined at two presentations of bleeding manifestations on five occasions - four times before therapy (prior to exposure to any blood products, including two examinations in outside laboratories) and once following 6 weeks of FFP transfusion which was administered at a frequency of one in 3-5 days. On all four pre-therapy occasions, the initial evaluation revealed prolongation of PT and aPTT with normal bleeding time and TT, suggesting a common pathway defect. Mixing studies performed with factor-deficient plasmas (FDPs) and factor assays revealed deficiency of factor $\mathrm{V}$ (table 1), and partial correction with control normal plasma indicated the presence of inhibitors by Rosner's index [4] and Chang's formula [5]. Performance of inhibitor screen revealed presence of both early and delayed acting inhibitors at initial presentations with subsequent disappearance after FFP transfusion. The disappearance of inhibitors was demonstrated by a lack of prolongation of PT (prolongation of at least 8-10 s indicates presence of inhibitors [6]) over the course of 1- and 2-hour incubation periods. On one occasion, aPTT failed to correct with plasmas deficient for factor V, X, VIII, or IX, indicating the presence of nonspecific inhibitors. Since defects in the common pathway disrupt testing and confirmation of lupus anticoagulants, ELISA tests were performed twice to highlight antiphospholipid antibodies ( $\beta 2$-glycoprotein, cardiolipin), but these were in the normal range, precluding them as nonspecific inhibitors causing the deficiency. The patient was on FFPs for 6 weeks with partial control of bleeding, and the tests were repeated 6 days after stopping FFP transfusions. The differences observed included negative inhibitor screen and complete correction on mixing studies but factor $\mathrm{V}$ level was still low (2\%).

\section{Discussion}

Inherited deficiency of factor $\mathrm{V}$, with mean age of onset of symptoms being 17 years [7], is difficult to differentiate clinically from acquired deficiency unless there is an identifiable preceding trigger, since both have a heterogeneous clinical phenotype. Subtle bleeding events, such as bleeding from nipple, umbilical stump, nose, gum and hematospermia, and also fatal intracranial bleedings have been reported [8-10]. Another unique feature of factor $\mathrm{V}$ is that, in contrast to other coagulation factor inhibitors, the risk of bleeding does not correlate with factor V inhibitor levels, prolongation of PT or aPTT, factor V activity, or the duration of presence of factor $\mathrm{V}$ inhibitor, thereby obviating the possibility to predict bleedings [11]. In cases of acquired deficiency, response is better with inhibitor eradication therapy [11].

Lack of family history of bleeding diathesis and evidence of presence of inhibitors at presentation in the index case favored acquired disease. Points favoring inherited deficiency included young age of onset of symptoms with no identifiable triggers for acquiring inhibitors. Since initial bleeding spontaneously regressed, the patient had been evaluated only 1 year later, which could explain the development of inhibitors in an inherited cause. This was further reaffirmed when, even after disappearance of inhibitors, there was persistent bleeding and reduced factor $\mathrm{V}$ levels. The indication of inhibitor activity against multiple factors on mixing studies with FDPs caused another dilemma. Lupus anticoagulant screen and ELISA tests for antibodies against $\beta 2$-glycoprotein and cardiolipin were negative, ruling out the presence of the most common nonspecific inhibitors. On search of literature for specificity of factor $\mathrm{V}$ inhibitors, it was noted that in some cases an inhibitor to one factor may interfere with the assay of other coagulation factors which had been best documented with FVIII inhibitors, but this finding could equally apply to any inhibitor [12].

\section{Conclusions}

Unanswered questions that confounded the diagnostic workup: 1) Spontaneous appearance of inhibitors with severe factor $V$ deficiency

2) Spontaneous disappearance of inhibitors without any inhibitor eradication therapy

3) Though the time for inhibitor disappearance has been described in some studies, it varied

4) After disappearance of inhibitors, the time for factor levels to rise back to normal is not clear.

In present article, we described an interesting case of severe inherited factor $\mathrm{V}$ deficiency with spontaneous appearance and disappearance of inhibitors exhibiting nonspecific factor inhibitory activity.

\section{Acknowledgements}

HS wrote the manuscript which was conceptually designed by RK; HS and PA performed the laboratory tests; $\mathrm{DC}, \mathrm{BH}$, and TKD were involved in patient care; and the detailed workup was guided and overseen by RK. DC, BH, PA, and TKD reviewed the manuscript and approved for submission.

\section{Disclosure Statement}

The authors declare that they have no interests which might be perceived as posing a conflict or bias. 


\section{References}

1 Wiwanitkit V: Spectrum of bleeding in acquired factor V Inhibitor: a summary of 33 cases. Clin Appl Thromb Hemost 2006;12:485-488.

2 Okoshi Y, Akiyama H, Inoue T, Koyama T, Kono N, Matsumura T, Mizuchi D, Mori S, Ohashi K, Sakamaki $\mathrm{H}$ : A long-lasting idiopathic factor $\mathrm{V}$ inhibitor (in Japanese). Rinsho Ketsueki 2003;44:14-18.

3 Bain B, Bates I, Laffan A (eds): Dacie and Lewis Practical Haematology, 11th ed. London, Churchill Livingstone, 2012.

4 Rosner E, Pauzner R, Lusky A, Modan M, Many A: Detection and quantitative evaluation of lupus circulating anticoagulant activity. Thromb Haemost 1987; 57:144-147.
5 Chang SH, Tillema V, Scherr D: A 'percent correction' formula for evaluation of mixing studies. Am J Clin Pathol 2002;117:62-73.

6 Van Cott EM, Laposata M: Coagulation; in Jacobs DS (ed): The Laboratory Test Handbook, 5th ed. Cleveland, Lexi-comp, 2001, pp 327-358.

7 Abdelwahab M, Khaddah N:. Rare coagulation disorders: a study of 70 cases in the Egyptian population. Haemophilia 2012;18:e386-e388.

8 Salooja N, Martin P, Khair K, Liesner R, Hann I: Severe factor $\mathrm{V}$ deficiency and neonatal intracranial hemorrhage: a case report. Haemophilia 2000;6:44-46.

9 Sigalas J, Roilides E, Tsanakas J, Karpouzas J: Bloody nipple discharge in infants. J Pediatr 1985;107:484.
10 Frotscher B, Toussaint-Hacquard M, Fouyssac F, Devignes J, Lecompte T, Briquel ME: Severe factor V deficiency in two brothers with different clinical presentations. Haemophilia 2012;18:e383-e385.

11 Ang AL, Kuperan P, Ng CH, Ng HJ: Acquired factor V inhibitor. A problem-based systematic review. Thromb Haemost 2009;101:852-859.

12 W Collins P, Chalmers E, Hart D, Jennings I, Liesner R, Rangarajan S, Talks K, Williams M, R M Hay C United Kingdom Haemophilia Centre Doctors' Organization: Diagnosis and management of acquired coagulation inhibitors: a guideline from UKHCDO. $\mathrm{Br}$ J Haematol 2013;162:758-773. 